\title{
Correction to: Interior boundary-aligned unstructured grid generation and cell-centered versus vertex-centered CVD-MPFA performance
}

\author{
Shahid Manzoor ${ }^{1}$ (D) $\cdot$ Michael G. Edwards $^{1}$ (D) - Ali H. Dogru ${ }^{2} \cdot$ Tareq M. Al-Shaalan $^{2}$
}

Published online: 17 November 2017

(c) Springer International Publishing AG, part of Springer Nature 2017

\section{Correction to: Comput Geosci}

https://doi.org/10.1007/s10596-017-9686-4

Due to an oversight, some author's corrections were not carried out during Performing proof corrections stage. The Publisher apologizes for these mistakes. The original article was corrected.

The online version of the original article can be found at https://doi.org/10.1007/s10596-017-9686-4.

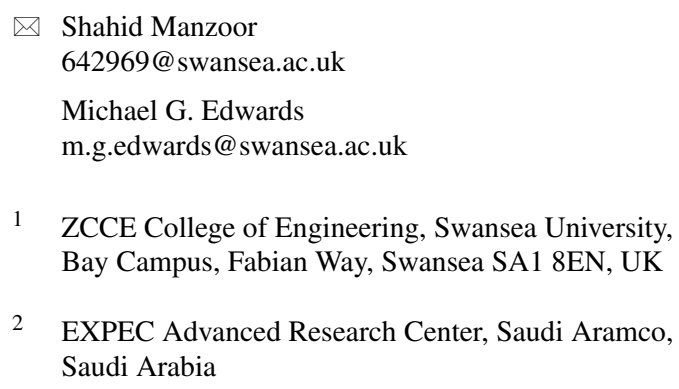

1 ZCCE College of Engineering, Swansea University, Bay Campus, Fabian Way, Swansea SA1 8EN, UK

2 EXPEC Advanced Research Center, Saudi Aramco, Saudi Arabia 